\title{
ANALISIS PENGARUH BELANJA LANGSUNG DAN BELANJA TIDAK LANGSUNG TERHADAP PERTUMBUHAN EKONOMI DAN DAMPAKNYA TERHADAP PENGENTASAN KEMISKINAN DI KABUPATEN/KOTA PROVINSI SULAWESI UTARA TAHUN 2010-2015
}

\author{
Marsye H. Kaat, Paulus Kindangen, Debby Ch. Rotinsulu \\ Fakultas Ekonomi dan Bisnis, Program Magister Ilmu Ekonomi \\ Universitas Sam Ratulangi
}

\begin{abstract}
ABSTRAK
Penelitian ini bertujuan mengetahui dan menjelaskan pengaruh belanja langsung dan belanja tidak langsung terhadap pertumbuhan ekonomi dan terhadap pengentasan kemiskinan baik secara langsung maupun tidak langsung pada kabupaten/kota Provinsi Sulawesi Utara tahun 2010 - 2015.

Penelitian ini menggunakan data sekunder yang berupa data belanja langsung, belanja tidak langsung, PDRB dan angka kemiskinan. Data diperoleh dari BPS Provinsi Sulawesi Utara, Badan Perencanaan Penelitian dan Pembangunan Daerah Provinsi Sulawesi Utara dan Badan Pengelolaan Keuangan dan Barang Milik Daerah Provinsi Sulawesi Utara. Untuk keperluan analisis dalam penelitian ini maka digunakan data panel di 15 (lima belas) kabupaten/kota yang ada di Provinsi Sulawesi Utara. Metode yang digunakan dalam penelitian ini analisis jalur untuk melihat pengaruh baik secara langsung maupun tidak langsung antara variabel eksogen dan endogen.

Hasil penelitian menunjukkan bahwa pertama, belanja langsung tidak berpengaruh terhadap pertumbuhan ekonomi. Kedua, belanja tidak langsung berpengaruh signifikan terhadap belanja langsung tidak berpengaruh terhadap pengentasan kemiskinan baik secara langsung maupun tidak langsung. Kelima, belanja tidak langsung berpengaruh terhadap pengentasan kemiskinan baik secara langsung maupun tidak langsung.
\end{abstract}

Kata kunci : Belanja Langsung, Belanja Tidak Langsung, Pertumbuhan Ekonomi dan Kemiskinan.

\begin{abstract}
This study aims to know and explain the effect of direct expenditure and indirect spending on economic growth and its impact on poverty alleviation in the district/cities of North Sulawesi Province in $2010-2015$.

This study uses secondary data in the form of data direct expenditure, indirect spending, Gross Reginal Domestic Product and poverty rate. Data were obtained from the Povincial BPS of North Sulawesi, Regional Planning, Research and Development Agencies of North Sulawesi and the Financial Management Agencies and Regional Property of North Sulawesi. For the purposes of analysis ini this study then used panel data in 15 districts/cities in North Sulawesi Province. The method used in this study path analysis to see the influence either directly or indirectly between exogenous variables and endogenous variables.

The results on this study show that first, direct spending has no effect on economic growth. Secon, indirect spending has an effect on economic growth. Third, economic growth has an effect on poverty alleviation. Fourth, direct expenditure has no effect on poverty alleviation either directly or indirectly. Fifth, indirect spending has an effect on poverty alleviation either directly or indirectly.
\end{abstract}

Keywords : direct expenditure, indirect spending, economic growth, poverty alleviation. 


\section{PENDAHULUAN}

\section{LATAR BELAKANG MASALAH}

Masalah kemiskinan dianggap sebagai salah satu hal yang menghambat proses pembangunan sebuah negara. Salah satu negara yang masih dibelit oleh masalah sosial ini adalah Indonesia. Angka kemiskinan di tingkat masyarakat masih cukup tinggi untuk Sulawesi Utara sebanyak 217.150 pada September 2015. Meskipun oleh lembaga statistik negara, selalu dinyatakan bahwa setiap tahun angka kemiskinan cenderung menurun. Kemiskinan merupakan masalah kompleks yang dihadapi oleh seluruh pemerintahan yang ada di dunia ini. Ia dipengaruhi oleh beberapa faktor yang saling berkaitan satu dengan lainnya. Faktor tersebut antara lain tingkat pendapatan, pendidikan, kesehatan, akses barang dan jasa, lokasi geografis, gender dan kondisi lingkungan (Rarity, 2013).

Menurut Asy'arie dalam Syawie (2011), persoalan kemiskinan itu terasa semakin dramatis karena berlangsung di negeri yang digambarkan sangat kaya sumber daya alam. Masih ada sebagian warga masyarakat untuk dapat makan sekali sehari saja sulit. Potret kemiskinan itu menjadi sangat kontras karena sebagian warga masyarakat hidup dalam kelimpahan, sementara sebagian lagi hidup serba kekurangan. Kekayaan bagi sejumlah orang berarti kemiskinan bagi orang lain. Tingkat kesenjangan luar biasa dan relatif cukup membahayakan.

Masalah yang banyak dihadapi oleh seluruh daerah dalam pelaksanaan desentralisasi fiskal yaitu kemiskinan. Hal ini menjadi masalah baik pada daerah perkotaan maupun perdesaan karena banyaknya masyarakat yang masih memiliki kemampuan rendah dalam membuka lapangan pekerjaan dan tidak banyak peluang masyarakat untuk mendapat pekerjaan serta banyaknya pekerja yang di-PHK karena para pengusaha kekurangan modal dan gulung tikar. Banyak upaya yang sudah dilakukan untuk menanggulangi kemiskinan yang terjadi namun upaya tersebut masih belum cukup dalam upaya mengentaskan kemiskinan.

Masalah kemiskinan di Provinsi Sulawesi Utara baik kabupaten dan kota merupakan salah satu prioritas pembangunan dalam jangka waktu 5 (lima) tahun melalui Program Operasi Daerah Selesaikan Kemiskinan (ODSK) dengan target penurunan kemiskinan sampai $40 \%$ di tahun 2021 sehingga semua program dan kegiatan diarahkan untuk menanggulangi kemiskinan. Sesuai arahan Visi dan Misi Presiden dan Wakil Presiden Republik Indonesia Jokowi dan Jusuf Kalla melalui Nawacita, penanggulangan kemiskinan merupakan program prioritas yang harus dilaksanakan oleh Pemerintah Pusat, Pemerintah Provinsi sampai ke Pemerintah Kabupaten dan Kota di Indonesia. Menurut Mankiw et. al dalam Maipita (2014), kebijakan fiskal merupakan bentuk campur tangan pemerintah dalam perekonomian dan pembangunan ekonomi suatu negara. Kebijakan fiskal memiliki dua instrument pokok, yaitu perpajakan (tax price) dan pengeluaran pemerintah (government expenditure).

Kebijakan pemerintah daerah dalam bentuk kebijakan fiskal melalui pengeluaran pemerintah daerah berupa belanja langsung dan belanja tidak langsung diharapkan dapat menanggulangi masalah kemiskinan sehingga angka kemiskinan di Sulawesi Utara dapat mengalami penurunan. Belanja daerah, atau yang dikenal dengan pengeluaran pemerintah daerah dalam anggaran pendapatan dan belanja daerah (APBD), merupakan salah satu faktor pendorong pertumbuhan ekonomi daerah. Karena itu, belanja daerah dikenal sebagai salah satu instrumen kebijakan fiskal yang dilakukan pemerintah (pemerintah daerah), di samping pos pendapatan pemerintah daerah.

Pengeluaran pemerintah daerah melalui belanja langsung maupun belanja tidak langsung merupakan alat intervensi pemerintah terhadap perekonomian yang dianggap paling efektif, 
selain kemampuan intervensi lainnya dari pemerintah. Keberhasilan suatu daerah dalam mewujudkan kesejahteraan masyarakat sangat tergantung pada kebijakan pemerintah daerah melalui alokasi belanjanya. Alokasi belanja yang baik tentunya diharapkan dapat meningkatkan kesejahteraan masyarakatnya. Pemerintah Daerah Provinsi Sulawesi Utara baik kabupaten maupun kota dalam menjalankan kebijakan anggarannya tentunya tetap mengacu pada ketentuan-ketentuan yang ada tentang pengelolaan keuangan daerah. Baik mulai dari proses perencanaan program dan kegiatan bahkan sampai pelaksanaan program kegiatan tetap berpedoman pada ketentuan yang ada. Pengeluran pemerintah daerah mulai tahun 2006 dikelompokan menjadi belanja langsung dan belanja tidak langsung. Namun pada tahun-tahun sebelumnya masih dikenal dengan belanja publik dan belanja aparatur.

Keberhasilan pembangunan di suatu daerah disamping ditentukan oleh besarnya pengeluaran pemerintah tersebut juga dipengaruhi oleh besarnya investasi. Investasi merupakan salah satu pilar pertumbuhan ekonomi, Investasi dapat menjadi titik tolak bagi keberhasilan dan keberlanjutan pembangunan di masa depan karena dapat menyerap tenaga kerja, sehingga dapat membuka kesempatan kerja baru bagi masyarakat yang pada gilirannya akan berdampak terhadap peningkatan pendapatan masyarakat, dan akhirnya akan menurunkan tingkat kemiskinan.

\section{RUMUSAN MASALAH}

Berdasarkan latar belakang permasalahan tersebut, maka yang menjadi pertanyaan dalam penelitian ini adalah:

1. Bagaimana pengaruh alokasi belanja langsung terhadap pertumbuhan ekonomi ?

2. Bagaimana pengaruh alokasi belanja tidak langsung terhadap pertumbuhan ekonomi?

3. Bagaimana pengaruh pertumbuhan ekonomi terhadap pengentasan kemiskinan ?

4. Bagaimana pengaruh alokasi belanja langsung terhadap pengentasan kemiskinan secara langsung maupun tidak langsung ?

5. Bagaimana pengaruh alokasi belanja tidak langsung terhadap pengentasan kemiskinan secara langsung maupun tidak langsung?

\section{TUJUAN PENELITIAN}

Berdasarkan masalah-masalah yang telah dikemukakan, maka tujuan yang ingin dicapai dari penelitian ini adalah untuk mengetahui dan menjelaskan :

1. Pengaruh alokasi belanja langsung terhadap pertumbuhan ekonomi

2. Pengaruh alokasi belanja tidak langsung terhadap pertumbuhan ekonomi

3. Pengaruh pertumbuhan ekonomi terhadap pengentasan kemiskinan

4. Pengaruh alokasi belanja langsung terhadap pengentasan kemiskinan secara langsung maupun tidak langsung.

5. Pengaruh alokasi belanja tidak langsung terhadap pengentasan kemiskinan secara langsung maupun tidak langsung.

\section{MANFAAT PENELITIAN}

Hasil penelitian ini diharapkan dapat memberi kegunaan sebagai berikut :

$>$ Sebagai bahan masukan bagi pemerintah Provinsi Sulawesi Utara untuk mengetahui perkembangan perekonomiannya, yang bisa berguna untuk informasi dalam pengembangan daerah terutama mengenai pengentasan kemiskinan. 
Untuk digunakan pihak yang berkepentingan untuk menganalisa masalah masalah yang berhubungan dengan pengelolaan fiskal Provinsi Sulawesi Utara

$>$ Sebagai bahan referensi bagi penelitian selanjutnya.

\section{TINJAUAN PUSTAKA}

\section{Kemiskinan dan Pengentasan Kemiskinan Kemiskinan}

Kemiskinan merupakan masalah kemanusiaan yang telah lama diperbincangkan karena berkaitan dengan kesejahteraan masyarakat dan upaya penanganannya. Dalam Panduan Keluarga Sejahtera (1996:10) kemiskinan adalah suatu keadaan dimana seorang tidak sanggup memelihara dirinya sendiri dengan taraf kehidupan yang dimiliki dan juga tidak mampu memanfaatkan tenaga, mental maupun fisik dalam memenuhi kebutuhannya.

\section{Pengentasan Kemiskinan}

Pengentasan Kemiskinan atau penurunan kemiskinan merupakan ukuran antara ekonomi dan kemanusian yang sangat diharapkan secara tetap (permanen) dapat mengangkat orang-orang (masyarakat) keluar dari kemiskinan.

\section{Pertumbuhan Ekonomi}

\section{Pengertian Pertumbuhan ekonomi}

Pertumbuhan ekonomi adalah proses kenaikan produksi suatu perekonomian yang diwujudkan dalam bentuk kenaikan pendapatan nasional. Suatu negara dikatakan mengalami pertumbuhan ekonomi apabila terjadi peningkatan GNP riil di negara tersebut.

\section{Teori Pertumbuhan Ekonomi}

Teori-teori pertumbuhan ekonomi yang berkembang antara lain: (Sadono Sukirno, 2006:243-270).

1. Teori Pertumbuhan Klasik,

2. Teori Pertumbuhan Harrod-Domar,

3. Teori Pertumbuhan Neo-Klasik,

4. Teori Schumpeter,

5. Teori Tahap-Tahap Pertumbuhan Ekonomi

\section{Manfaat Pertumbuhan ekonomi}

Menurut Sanusi (2004), pertumbuhan ekonomi merupakan upaya untuk mengurangi tingkat kemiskinan absolut, tetapi di sebagian besar negara-negara berkembang pertumbuhan ekonomi saja tampaknya tidak cukup. Anggapan ini tampaknya terpusat pada teori dan kebijaksanaan pembangunan yang masih membutuhkan pengkajian lebih lanjut. Muncul pertanyaan yang mendasar mengenai hal ini seperti: Apakah dengan pertumbuhan ekonomi yang terlukis dengan adanya kenaikan GNP cenderung akan memperbaiki atau memperburuk atau sama sekali tidak mempunyai pengaruh terhadap distribusi pendapatan dan standar kemiskinan di negara-negara berkembang. Tingkat pertumbuhan yang cepat semata-mata bukan suatu yang menentukan distribusi pendapatan. Adanya perdebatan mengenai karakter pertumbuhan ekonomi itu dibahas lebih lanjut dalam suatu studi lapangan yang diselenggarakan di 43 negara 
berkembang. Tujuan studi lapangan tersebut untuk menganalisis hubungan antara peranan pendapatan dari kelompok $60 \%$ penduduk miskin dan kegiatan ekonomi suatu negara secara keseluruhan. Dari penelitian tersebut diketahui bahwa efek dari pembangunan ekonomi yang prinsipil terhadap distribusi pendapatan secara rata-rata ternyata sudah menurunkan pendapatan absolut dan pendapatan relatif golongan miskin. Memang tidak ada bukti yang menunjukkan bahwa ada manfaat yang menetes ke bawah secara otomatis (trickle down effect) dari pertumbuhan ekonomi. Justru sebaliknya proses pertumbuhan dialami oleh 43 negara berkembang itu sudah menguntungkan (trickle down effect) golongan masyarakat menengah dan terutama menguntungkan bagi yang kaya yang jumlahnya sedikit. Oleh karena itu dapat disimpulkan bahwa struktur ekonomi, dan bukannya standar atau tingkat pertumbuhan ekonomi, yang merupakan faktor penentu pola dstribusi pendapatan.

\section{Pengertian Belanja Daerah}

Belanja daerah adalah semua pengeluaran yang dilakukan pemerintah daerah dalam periode anggaran tertentu digunakan untuk melaksanakan kewajiban, wewenang dan tanggung jawab dari pemerintah daerah kepada masyarakat dan pemerintah daerah.

\section{Tujuan Belanja Daerah}

a. Merupakan rasionalisasi atau gambaran kemampuan dan penggunaan sumber-sumber finansial dan material yang tersedia pada suatu negara/daerah

b. Sebagai upaya untuk penyempurnaan berbagai rencana kegiatan yang telah dilaksanakan sebelumnya sehingga hasilnya akan lebih baik

c. Sebagai alat untuk memperinci penggunaan sumber-sumber yang tersedia menurut objek pembelanjaannya sehingga memudahkan pengawasan atas pengeluarannya

d. Sebagai landasan yuridis formal dari penggunaan sumber penerimaan yang dapat dilakukan pemerintah serta sebagai alat untuk pembatasan pengeluaran

e. Sebagai alat untuk menampung, menanalisis serta mempertimbangkan dalam membuat keputusan seberapa besar alokasi pembayaran program dan proyek yang diusulkan

f. Sebagai pedoman atau tolok ukur serta alat pengawasan atas pelaksanaan kegiatan, program dan proyek yang dilakukan pemerintah.

\section{Hubungan Belanja Daerah dengan Pertumbuhan Ekonomi}

Pengeluaran pemerintah akan semakin meningkat seiring dengan peningkatan perekonomian suatu Negara. Meskipun demikian peningkatan pengeluaran pemerintah belum tentu berakibat baik terhadap aktivitas perekonomian. Oleh karena itu perlu dilihat efisiensi penggunaan pengeluaran pemerintah tersebut (Berutu dalam Larengkum, 2013). 


\section{Kerangka Konseptual}

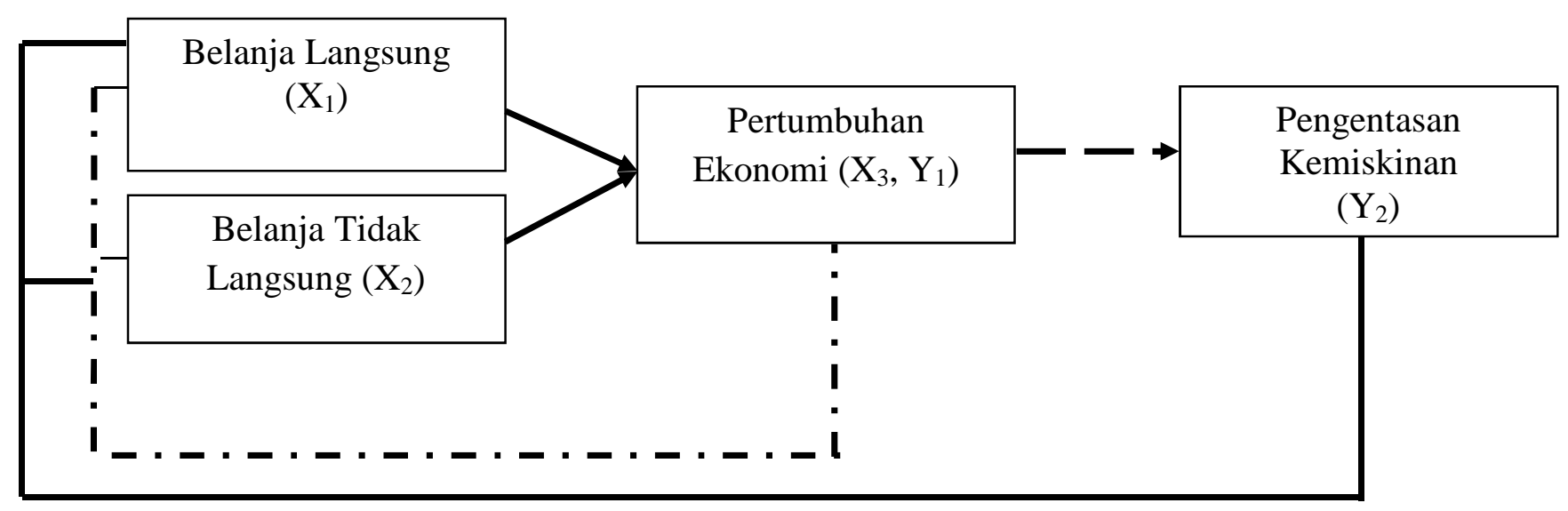

\footnotetext{
$\longrightarrow$ Pengaruh Partial Belanja Langsung dan Belanja Tidak Langsung Terhadap Pertumbuhan Ekonomi

- - - $\rightarrow$ Pengaruh Partial Pertumbuhan Ekonomi terhadap Pengentasan Kemiskinan

-_-_-_ Pengaruh Gabungan/agregat Belanja Langsung dan Belanja Tidak Langsung terhadap

Pertumbuhan Ekonomi

Pengaruh Gabungan/agregat Belanja langsung dan belanja tidak langsung serta pertumbuhan ekonomi Terhadap Pengentasan Kemiskinan

\section{Hipotesis}

1) Diduga belanja langsung mempunyai pengaruh terhadap pertumbuhan ekonomi

2) Diduga belanja tidak langsung mempunyai pengaruh terhadap pertumbuhan ekonomi

3) Diduga pertumbuhan ekonomi mempunyai pengaruh terhadap pengentasan kemiskinan

4) Diduga belanja langsung mempunyai pengaruh terhadap pengentasan kemiskinan baik secara langsung maupun tidak langsung

5) Diduga belanja tidak langsung mempunyai pengaruh terhadap pengentasan kemiskinan baik secara langsung maupun tidak langsung
}

\section{METODE PENELITIAN}

\section{Jenis Penelitian dan Data}

Data yang digunakan dalam penelitian ini merupakan data sekunder kuantitatif berupa data belanja langsung, belanja tidak langsung, PDRB dan angka kemiskinan, dengan metode penelitian menggunakan analisis jalur, dengan menggunakan data panel di 15 kabupaten/kota yang ada di Provinsi Sulawesi Utara yang bersumber dari Badan Pusat Statistik Provinsi Sulawesi Utara, Badan Perencanaan Penelitian dan Pembangunan Daerah Provinsi Sulawesi Utara dan Badan Pengelola Keuangan dan Barang Milik Daerah Provinsi Sulawesi Utara.

\section{Metode Analisis}

Metode analisis yang akan digunakan dalam penelitian ini adalah analisis path. Yaitu untuk mengetahui pengaruh variabel independen terhadap variabel dependen yang diformulasikan yang ditunjukkan pada persamaan (dibawah). 
dimana,

$$
\begin{array}{lllll}
\mathrm{PE}=\mathrm{f}(\mathrm{BL}, \mathrm{BTL}) & . & . & . & . \\
\mathrm{PK}=\mathrm{f}(\mathrm{PE}) & . & . & . & .
\end{array}
$$

$$
\begin{aligned}
& \mathrm{PK}=\text { Pengentasan Kemiskinan } \\
& \mathrm{BL}=\text { Belanja Langsung } \\
& \mathrm{BTL}=\text { Belanja Tidak Langsung } \\
& \mathrm{PE}=\text { Pertumbuhan Ekonomi }
\end{aligned}
$$

Dari model fungsional persamaan (3.1) dan (3.1.1) dapat ditulis secara model ekonometrika sebagai berikut :

$$
\begin{aligned}
& \mathrm{PE}_{\mathrm{t}}=\beta_{0}+\beta_{1} \mathrm{BL}_{\mathrm{t}}+\beta_{2} \mathrm{BTL}_{\mathrm{t}}+\mathrm{e}_{\mathrm{t}} \\
& \mathrm{PK}_{\mathrm{t}}=\beta_{0}+\beta_{1} \mathrm{PE}_{\mathrm{t}}+\mathrm{e}_{\mathrm{t}}
\end{aligned}
$$

dimana,

$\mathrm{BL}=$ Belanja Langsung

BTL = Belanja Tidak Langsung

$\mathrm{PE} \quad=$ Pertumbuhan Ekonomi

$\mathrm{PK} \quad=$ Pengentasan Kemiskinan

$\beta_{0} \quad=$ konstanta (intersep)

$\beta_{1}, \beta_{2}, \beta_{3}=$ koefisien regresi dari masing-masing variabel bebas,

$\mathrm{e}=$ error term

$\mathrm{t}=$ tahun atau periode (tahun 2010-2015)

Persamaan (3.2) dan (3.2.2) ditransformasikan kedalam bentuk log-natural seperti yang ditunjukkan persamaan (3.3) dan (3.3.1). Pentransformasian ke dalam bentuk log-natural bertujuan untuk menjadikan nilai variabel-variabel yang dianalisis menjadi seimbang dan juga sekaligus hasil output regresi menunjukkan koefisien slope merupakan tingkat perubahan variabel tidak bebas (dalam persen) bila terjadi perubahan variabel-variabel bebas (dalam persen) Nachrowi, (2006).

$$
\begin{aligned}
& \mathrm{LPE}_{\mathrm{t}}=\beta_{0}+\beta_{1} \mathrm{LBL}_{\mathrm{t}}+\beta_{2} \mathrm{LBTL}_{\mathrm{t}}+\mathrm{e}_{\mathrm{t}} \\
& \mathrm{LPM}_{\mathrm{t}}=\beta_{0}+\beta_{1} \mathrm{PE}_{\mathrm{t}}+\mathrm{e}_{\mathrm{t}}
\end{aligned}
$$

dimana,

$$
\begin{aligned}
& \text { LBL }=\text { Laju Belanja Langsung } \\
& \text { LBTL }=\text { Laju Belanja Tidak Langsung } \\
& \text { LPM }=\text { Laju Pengentasan Kemiskinan } \\
& \text { LPE }=\text { Laju Pertumbuhan Ekonomi }
\end{aligned}
$$

\section{Definisi Operasional Variabel}

Berdasarkan klasifikasi variabel dan kerangka konseptual, maka variabel didefinisikan sebagai berikut:

1. Belanja Langsung adalah belanja yang berkaitan langsung dengan program/kegiatan suatu daerah (pembangunan) ditetapkan dalam APBD untuk satu tahun anggaran dengan sumber anggaran berasal dari Pendapatan Asli Daerah (PAD) yang ditunjang dengan alokasi anggaran dari Pemerintah Pusat berupa Dana Alokasi Umum (DAU), diukur dalam (milyar Rupiah).

2. Belanja Tidak Langsung belanja yang tidak berkaitan langsung dengan program/kegiatan yang ditetapkan dalam APBD untuk satu tahun anggaran dengan jenis belanja dibagi menjadi belanja pegawai (gaji dan tunjangan lain para Aparatur 
Sipil Negara), belanja subsidi, belanja hibah, belanja bantuan sosial, belanja bagi hasil, belanja bantuan keuangan dan belanja tidak terduga, diukur dalam (milyar Rupiah).

3. Pertumbuhan Ekonomi adalah proses perubahan kondisi perekonomian suatu negara secara berkesinambungan menuju keadaan yang lebih baik selama periode tertentu yang diwujudkan dalam bentuk kenaikan pendapatan regional daerah, diukur dalam (juta Rupiah).

4. Pengentasan Kemiskinan adalah merupakan ukuran antara ekonomi dan kemanusiaan yang sangat diharapkan secara tetap dapat mengangkat orang-orang keluar dari kemiskinan untuk selanjutnya dapat meningkatkan kualitas hidup, diukur dalam (jiwa/kepala).

\section{HASIL PENELITIAN DAN PEMBAHASAN}

\section{Hasil Penelitian \\ Pengujian Asumsi klasik Multikorelasi}

Tabel 1. VIF

\begin{tabular}{|c|c|c|}
\hline \multicolumn{2}{|c|}{ Model } & Collinearity Statistics \\
\hline & & VIF \\
\hline \multirow{3}{*}{1} & (Constant) & \\
\hline & $x 2$ & 1.185 \\
\hline & $\mathrm{x} 1$ & 1.185 \\
\hline
\end{tabular}

a. Dependent Variable: PE

\section{Sumber Data : pengolahan data 2017}

Dilihat dari tabel 1. Coefficients nilai VIF pada output menunjukkan keberadaan multikolinearitas.

Bila VIF $<10,00$ maka tidak terjadi gejala Multikorelasi

Bila VIF > 10,00 maka terjadi gejala Multikorelasi

Dengan Hasil :

$$
\begin{array}{lll}
\text { Nilai VIF } & \mathrm{X}_{1} \text { belanja langsung } & =1.185 \\
\mathrm{X}_{2} \text { belanja tidak langsung } & =1.185
\end{array}
$$

Dari hasil perhitungan di atas dapat dilihat bahwa nilai VIF kedua variabel independent berada pada angka dibawah 10 hal ini menunjukan bahwa tidak terjadi gejala multikolinearitas sehingga data penelitian layak dan dapat digunakan. 


\section{Diagram Uji Heterokedastisitas}

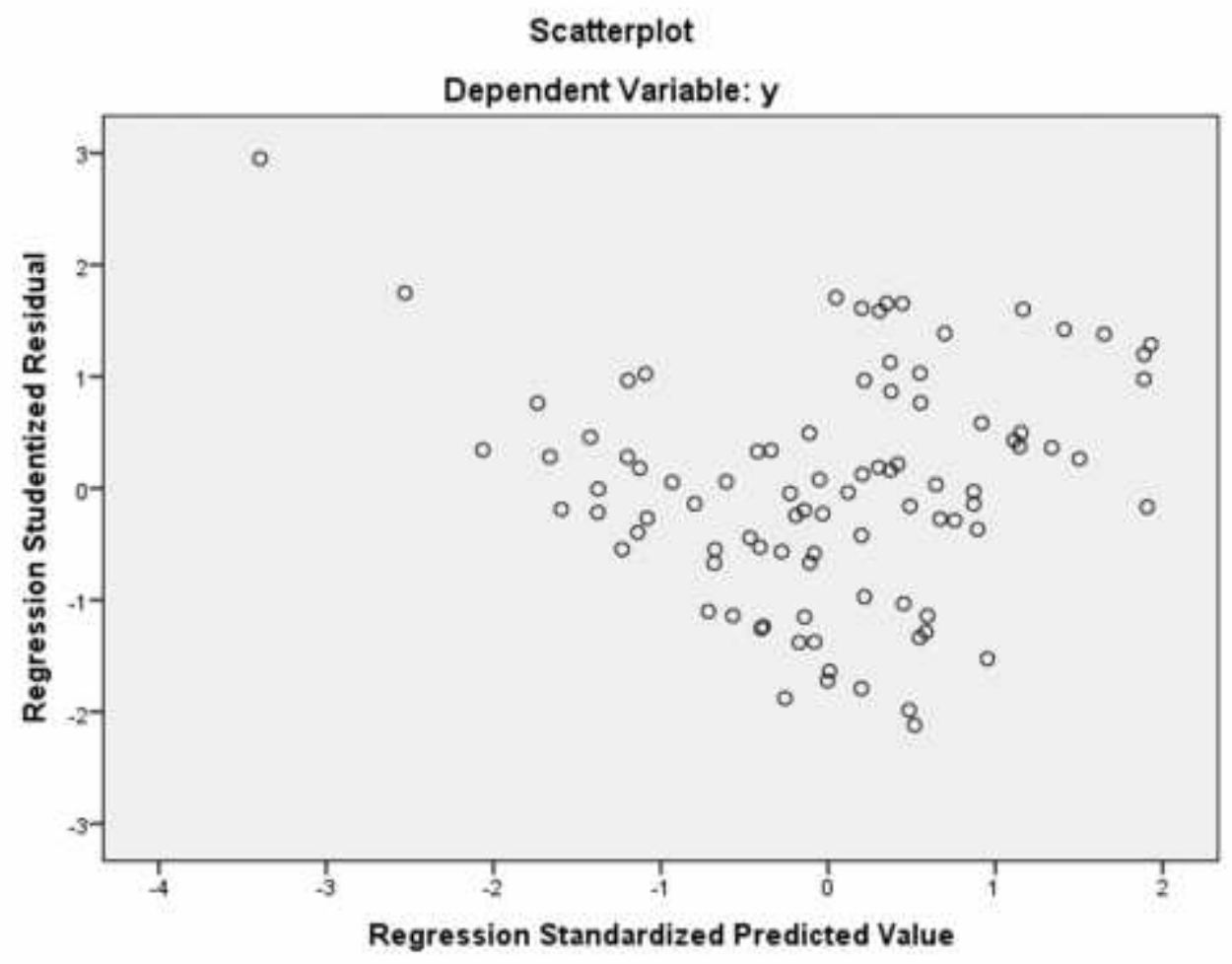

Dari diagram diatas tersebut terlihat bahwa penyebaran residual tidak teratur. Hal tersebut terlihat pada plot yang terpancar dan tidak membentuk pola tertentu. Dengan hasil demikian, kesimpulan yang biasa diambil adalah bahwa tidak terjadi gejala homokedastisitas atau persamaan regresi memenuhi asumsi heterokedastisitas.

\section{Uji Autokorelasi}

Tabel 2. Durbin Watson

Model Summary

\begin{tabular}{|c|c|c|c|}
\hline \multirow[t]{2}{*}{ Model } & \multicolumn{2}{|c|}{ Change Statistics } & \multirow[t]{2}{*}{ Durbin-Watson } \\
\hline & df2 & Sig. F Change & \\
\hline 1 & $87^{a}$ & .000 & .378 \\
\hline
\end{tabular}

a. Predictors: (Constant), $\mathrm{x}_{1}, \mathrm{x}_{2}$

b. Dependent Variable: $\mathrm{y}$

Sumber Data : pengolahan data 2017

Pada analisis regresi telihat bahwa nilai DW 0,378 dan nilai DL 0.455, dan DU 2,287 . DL < DW < DU yakni 0.455 DL, 0,568 DW, 2.287 DU berada pada antara DL dan DU dan 
berada pada titik keragu-raguan. Maka dapat disimpulkan bahwa terdapat gejala autokorelasi yang lemah.

\section{Penghitungan Kofisien Determinasi}

Tabel 3. Koefisien Determinasi

Model Summary

\begin{tabular}{|l|r|r|r|r|r|r|r|}
\hline Model & \multicolumn{1}{|c|}{$\mathrm{R}$} & R Square & $\begin{array}{c}\text { Adjusted R } \\
\text { Square }\end{array}$ & & & $\begin{array}{c}\text { Std. Error of } \\
\text { the Estimate }\end{array}$ & \multicolumn{3}{|c|}{ Change Statistics } \\
\cline { 5 - 8 } & & & & $\begin{array}{c}\text { R Square } \\
\text { Change }\end{array}$ & F Change & df1 \\
\hline 1 & $.799^{\mathrm{a}}$ & .638 & .630 & .23179 & .638 & 76.609 & 2 \\
\hline
\end{tabular}

a Predictors: (Constant), $\mathrm{X}_{1}, \mathrm{X}_{2}$

b Dependent Variable: $\mathrm{Y}_{1}$

Sumber Data : pengolahan data 2017

Besarnya pengaruh variabel independen belanja langsung dan belanja tidak langsung terhadap variabel dependen pertumbuhan ekonomi secara gabungan adalah 63,8\%. Besarnya faktor lain yang mempengaruhi diluar model yang diteliti sebesar 34,2\% (e).

\section{Pengaruh variabel Independen Belanja Langsung dan Belanja Tidak Langsung secara parsial terhadap variabel Dependen Pertumbuhan Ekonomi.}

Besarnya pengaruh variabel independen belanja langsung dan belanja tidak langsung terhadap variabel dependen pertumbuhan ekonomi secara parsial dapat dilihat dari nilai beta atau standardized coefficients dan untuk pengujian digunakan nilai $\mathrm{t}$, dapat dilihat pada Tabel 5 . dibawah ini

\section{Tabel 4. Coefficients(a)}

\begin{tabular}{|c|c|c|c|c|c|c|}
\hline \multirow{2}{*}{\multicolumn{2}{|c|}{ Model }} & \multicolumn{2}{|c|}{ Unstandardized Coefficients } & Standardized & \multirow[t]{2}{*}{$\mathrm{t}$} & \multirow[t]{2}{*}{ Sig. } \\
\hline & & B & Std. Error & Beta & & \\
\hline \multirow{3}{*}{1} & (Constant) & -6.705 & 1.847 & & -3.629 & .000 \\
\hline & $x 2$ & 1.340 & .114 & .826 & 11.767 & .000 \\
\hline & $\mathrm{x} 1$ & -.189 & 169 & -.079 & -1.121 & 266 \\
\hline
\end{tabular}

Dependent Variable: Pertumbuhan Ekonomi $\left(\mathrm{Y}_{1}\right)$

Sumber Data : pengolahan data 2017

\section{Pengaruh Variabel Independen Belanja Langsung terhadap Variabel Dependen Pertumbuhan Ekonomi.}

Untuk melihat apakah ada pengaruh linier variabel independen belanja langsung terhadap variabel dependen pertumbuhan ekonomi. Dapat dilihat pada tabel 5. coefficients (a) dengan analisis :

Hipotesis :

1. H0 : Tidak ada pengaruh linier variabel independen belanja langsung terhadap variabel dependen pertumbuhan ekonomi. 
2. $\quad \mathrm{H} 1$ : ada pengaruh linier variabel independen belanja langsung terhadap variabel dependen pertumbuhan ekonomi

Menentukan besarnya taraf signifikan sebesar 0,05 dan degree of freedom $\mathrm{DF}=\mathrm{n}-(\mathrm{K}+1)$ atau $\mathrm{DF}=90-(2+1)=87$. Dari ketentuan tersebut diperoleh t tabel sebesar 1,662 (untuk uji dua arah)

Dalam perhitungan SPSS yang tertera pada tabel coefficients di atas dimana tabel $\mathrm{t}$ adalah untuk menunjukan bahwa adanya pengaruh variabel independen belanja langsung terhadap variabel dependen pertumbuhan ekonomi ialah -1.121.

Pengujian hipotesis t kriterianya sebagai berikut :

1. Jika thitung $\geq \mathrm{t}$ tabel, maka $\mathrm{H} 0$ ditolak, dan $\mathrm{H} 1$ diterima

2. $\quad$ Jika thitung $\leq \mathrm{t}$ tabel, maka H0 diterima, dan $\mathrm{H} 1$ ditolak

Dimana dalam melihat pengaruh signifikan atau tidak Kriterianya adalah sebagai berikut :

1. Jika signifikan $\leq 0,05$ maka berpengaruh signifikan

2. Jika Signifikan $\geq 0,05$ maka tidak ada pengaruh signifikan

Hasil dari perhitungan dengan SPSS menunjukan angka t hitung sebesar $-1.121 \leq \mathrm{t}$ tabel sebesar 1,662. Dengan demikian keputusanya ialah H0 diterima, dan H1 ditolak. Artinya tidak ada pengaruh variabel independen belanja langsung terhadap variabel dependen pertumbuhan ekonomi. Maka variabel independen belanja langsung tidak berpengaruh terhadap variabel dependen pertumbuhan ekonomi.

Besarnya koefisien beta pada tabel 5. di atas (dalam kolom standardized coefficient beta) sebesar $-0,792$ atau jika dibuat persen menjadi sebesar $-79,2 \%$ menunjukan bahwa pengaruh sebesar ini tidak signifikan karena nilai signifikansi / probabilitas hasil yang tertera pada kolom Sig 0,266 > 0,05 .

\section{Pengaruh variabel independen belanja tidak langsung terhadap variabel dependen pertumbuhan ekonomi.}

Untuk melihat apakah ada pengaruh variabel independen belanja tidak langsung terhadap variabel dependen pertumbuhan ekonomi. Dapat dilihat pada tabel 5. coefficients (a) dengan analisis :

Hipotesis :

1. HO : tidak ada pengaruh linier variabel independen belanja tidak langsung terhadap variabel dependen pertumbuhan ekonomi.

2. $\quad \mathrm{H} 1$ : ada pengaruh linier variabel independen belanja tidak langsung terhadap variabel dependen pertumbuhan ekonomi

Menentukan besarnya taraf signifikan sebesar 0,05 dan degree of freedom $\mathrm{DF}=\mathrm{n}-(\mathrm{K}+1)$ atau $\mathrm{DF}=90-(2+1)=87$. Dari ketentuan tersebut diperoleh t tabel sebesar 1,662 (untuk uji dua arah)

Dalam perhitungan SPSS yang tertera pada tabel coefficients di atas dimana tabel t adalah untuk menunjukan bahwa adanya pengaruh variabel independen belanja langsung terhadap variabel dependen pertumbuhan ekonomi ialah 11,767.

Pengujian Hipotesis t kriterianya sebagai berikut :

1. Jika thitung $\geq \mathrm{t}$ tabel, maka $\mathrm{H} 0$ ditolak, dan $\mathrm{H} 1$ diterima

2. Jika thitung $\leq \mathrm{t}$ tabel, maka $\mathrm{H} 0$ diterima, dan $\mathrm{H} 1$ ditolak

Dimana dalam melihat pengaruh signifikan atau tidak Kriterianya adalah sebagai berikut : 
1. Jika signifikan $\leq 0,05$ maka berpengaruh signifikan

2. Jika signifikan $\geq 0,05$ maka tidak ada pengaruh signifikan

Hasil dari perhitungan dengan SPSS menunjukan angka t hitung sebesar 11,767 > t tabel sebesar 1,662. Dengan demikian keputusanya ialah H0 ditolak, dan H1 diterima. Artinya ada hubungan linier variabel independen belanja tidak langsung terhadap variabel dependen pertumbuhan ekonomi. Maka variabel independen belanja tidak langsung berpengaruh terhadap variabel dependen pertumbuhan ekonomi.

Besarnya koefisien beta pada tabel 4. di atas (dalam kolom standardized coefficient beta) sebesar 0,826 atau jika dibuat persen menjadi sebesar $82,6 \%$ menunjukan bahwa pengaruh sebesar ini signifikan karena nilai signifikansi/probabilitas hasil yang tertera pada kolom sig $0,00<0,05$.

\section{Melihat Kelayakan Model Regresi}

Untuk mengetahui model regresi yang telah dibuat sudah benar adalah dengan menggunakan pengujian dengan menggunakan pengujian dengan dua cara, yaitu pertama menggunakan nilai $\mathrm{F}$ pada tabel keluaran ANOVA, dan kedua dengan cara menggunakan nilai probabilitas/nilai sig pada tabel keluaran ANOVA.

Tabel 5. ANOVA(b)

\begin{tabular}{|rl|r|r|r|r|r|}
\hline Model & & Sum of Squares & df & Mean Square & F & Sig. \\
\hline \multirow{2}{*}{1} & Regression & 8.232 & 2 & 4.116 & 76.609 & $.000^{\circ}$ \\
& Residual & 4.674 & 87 & .054 & & \\
& Total & 12.906 & 89 & & & \\
\hline
\end{tabular}

a. Dependent Variable: y

b. Predictors: (Constant), $\mathrm{x}_{1}, \mathrm{x}_{2}$

Sumber Data : pengolahan data 2017

Uji Hipotesis Menggunakan Angka F.

Hipotesis :

1. H0 : tidak ada pengaruh linier variabel independen belanja langsung dan belanja tidak langsung terhadap variabel dependen pertumbuhan ekonomi.

2. H1 : ada pengaruh linier variabel independen belanja langsung dan belanja tidak langsung terhadap variabel dependen pertumbuhan ekonomi.

Menghitung nilai $\mathrm{F}$ tabel dengan ketentuan besar nilai taraf signifikansi sebesar 0,05 dan nilai degree of freedom dengan ketentuan numerator /vektor 1 : jumlah variabel -1 atau $3-1=$ 2 , dan dumerator /vektor 2 : jumlah kasus-jumlah variabel atau $90-3=87$. Dengan ketentuan terdebut diperoleh angka $\mathrm{F}$ tabel sebesar 3.100.

Dengan kriteria pengambilan keputusan hasil pengujian hipotesis

Jika $\mathrm{F}$ hitung $\geq \mathrm{F}$ tabel, maka $\mathrm{H} 0$ ditolak, $\mathrm{H} 1$ diterima.

Jika $\mathrm{F}$ hitung $\leq \mathrm{F}$ tabel, maka $\mathrm{H} 0$ diterima dan $\mathrm{H} 1$ ditolak.

Hasil uji hipotesis adalah :

Hasil perhitungan dengan SPSS didapatkan angka F hitung sebesar $76.609>\mathrm{F}$ tabel sebesar 3,100. Dengan demikian H0 ditolak, dan H1 diterima. Artinya ada hubungan linier variable independen belanja langsung dan belanja tidak langsung dengan variabel dependen endogenus pertumbuhan ekonomi. Dengan nilai sig 0,000. Kesimpulan adalah model regresi di atas sudah layak dan benar. 


\section{Perhitungan Sub Struktur II}

Tabel 6. Coefficients(a)

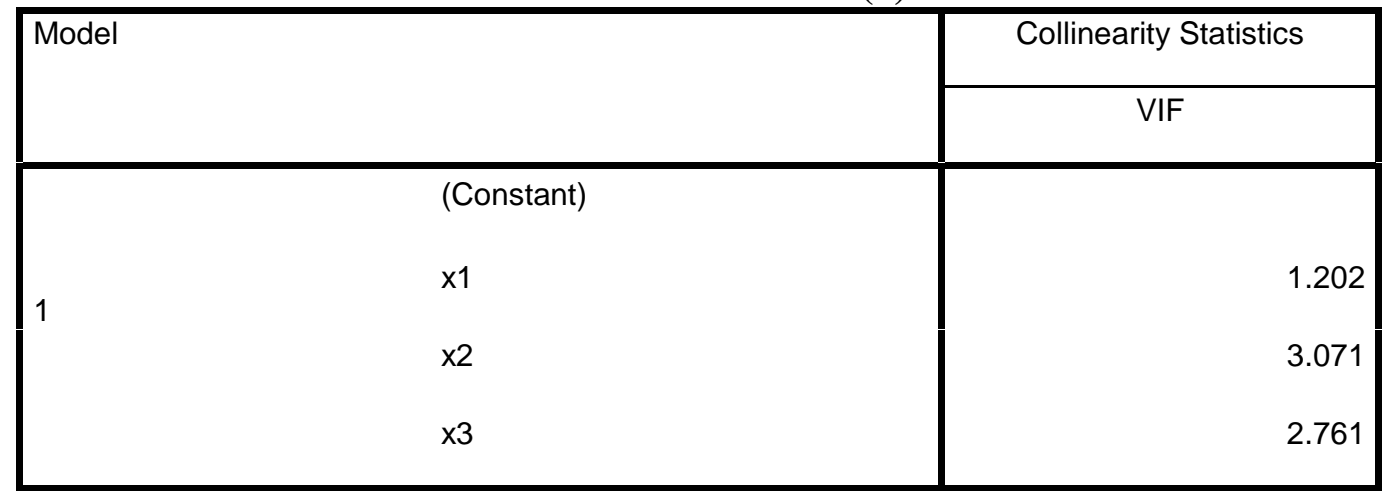

Dependent Variabel: Pengentasa Kemiskinan

Sumber Data : pengolahan data 2016

Dilihat dari Tabel Coefficients ${ }^{a}$ nilai VIF pada output menunjukan keberadaan multikolinearitas tidak signifikan, artinya tidak ada indikasi Multikolinearitas dalam model. Ini ditunjukan dengan nilai VIF berturut-turut untuk $\mathrm{X}_{1}$ Belanja Langsung, $\mathrm{X}_{2}$ Belanja Tidak Langsung, dan $\mathrm{X}_{3}$ Pertumbuhan Ekonomi adalah lebih kecil dari 10,0.

Pengaruh Variabel Independen Belanja Langsung, Belanja Tidak Langsung dan Pertumbuhan Ekonomi Secara Gabungan Terhadap Variabel Dependen Pengentasan Kemiskinan.

Tabel 7. Model Summary(b)

\begin{tabular}{|c|c|c|c|c|c|c|c|}
\hline \multirow[t]{2}{*}{ Model } & \multirow[t]{2}{*}{$\mathrm{R}$} & \multirow[t]{2}{*}{ R Square } & \multirow{2}{*}{$\begin{array}{l}\text { Adjusted R } \\
\text { Square }\end{array}$} & \multirow{2}{*}{$\begin{array}{l}\text { Std. Error of } \\
\text { the Estimate }\end{array}$} & \multicolumn{3}{|c|}{ Change Statistics } \\
\hline & & & & & $\begin{array}{l}\text { R Square } \\
\text { Change }\end{array}$ & F Change & df1 \\
\hline 1 & $.772^{\mathrm{a}}$ & .596 & .582 & .15034 & .596 & 42.289 & 3 \\
\hline
\end{tabular}

a Predictors: (Constant): $\mathrm{X}_{1}, \mathrm{X}_{2}, \mathrm{X}_{3} / \mathrm{Y}_{1}$

b Dependent Variable: $\mathrm{Y}_{2}$

Sumber Data : pengolahan data 2017

Besarnya pengaruh $\mathrm{R}$ square $\left(\mathrm{R}^{2}\right)$ pada tabel diatas adalah 0,561. Angka tersebut mempunyai makna besarnya pengaruh variabel independen belanja langsung, dan belanja tidak langsung serta pertumbuhan ekonomi secara gabungan terhadap pengentasan kemiskinan sebesar $59,6 \%$ sedangkan besarnya pengaruh dari variabel diluar model adalah sebesar 40,4\%.

Pengaruh Variabel Independen Belanja Langsung dan Belanja Tidak Langsung serta Pertumbuhan Ekonomi secara Parsial terhadap Variabel Dependen Pengentasan Kemiskinan. 
Besarnya pengaruh variabel independen belanja langsung, belanja tidak langsung serta pertumbuhan ekonomi terhadap pengentasan kemiskinan secara parsial.

Tabel 8. Coefficients(a)

\begin{tabular}{|c|c|c|c|c|c|}
\hline \multirow[t]{2}{*}{ Model } & \multicolumn{2}{|c|}{ Unstandardized Coefficients } & \multirow{2}{*}{$\begin{array}{c}\begin{array}{c}\text { Standardized } \\
\text { Coefficients }\end{array} \\
\text { Beta }\end{array}$} & \multirow[t]{2}{*}{$\mathrm{t}$} & \multirow[t]{2}{*}{ Sig. } \\
\hline & B & Std. Error & & & \\
\hline (Constant) & -.470 & 1.286 & & -.365 & .716 \\
\hline $\mathrm{x} 1$ & -.114 & .110 & -.078 & -1.032 & .305 \\
\hline $\mathrm{x} 2$ & .342 & .119 & .346 & 2.877 & .005 \\
\hline$x 3$ & .300 & .070 & .491 & 4.309 & .000 \\
\hline
\end{tabular}

Dependent Variable: $\mathrm{Y}_{2}$ (Pengentasan Kemiskinan)

Sumber Data : pengolahan data 2017

\section{Pengaruh antara Variabel Independen Belanja Langsung dengan Variabel Dependen Pengentasan Kemiskinan.}

Dengan hipotesis :

1. H0 : tidak ada pengaruh linier variabel independen belanja langsung terhadap variabel dependen pengentasan kemiskinan

2. H1 : adanya pengaruh linier antara variabel independen belanja langsung terhadap variabel dependen pengentasan kemiskinan

Dari hasil perhitungan dengan menggunakan SPSS yang tertera pada kolom $\mathrm{t}$ pada tabel coefficients diatas untuk menunjukan adanya hubungan linier antara variabel independen belanja langsung dengan variabel dependen pengentasan kemiskinan ialah sebesar -1,032.

Menentukan besarnya angka $t$ tabel / nilai kritis dari tabel $t$ dengan ketentuan sebagai berikut :

Menentukan besarnya taraf signifikansi sebesar 0,05 dan degree of freedom DF dengan ketentuan : $\mathrm{DF}=\mathrm{n}-(\mathrm{K}+1)$ atau $\mathrm{DF}=90-(3+1)$ dari ketentuan tersebut diperoleh angka $\mathrm{t}$ tabel untuk uji dua sisi adalah sebesar 1,662

Dalam pengujian hipotesis $t$ kriterianya sebagai berikut :

Jika thitung $\geq \mathrm{t}$ tabel, maka $\mathrm{H} 0$ di tolak dan $\mathrm{H} 1$ diterima

Jika thitung $\leq \mathrm{t}$ tabel, maka $\mathrm{H} 0$ diterima dan $\mathrm{H} 1$ ditolak

Untuk menunjukan pengaruh signifikan atau tidak kriterianya sebagai berikut :

Jika Sig $\leq 0,05$, maka berpengaruh signifikan

Hasil Pengujian :

Jika Sig $\geq 0,05$, maka tidak berpengaruh signifikan 
Hasil dari perhitungan dengan menggunakan SPSS menunjukan angka t hitung sebesar -1,032.< 1,662, dengan demikian keputusanya adalah H0 diterima, dan H1 ditolak. Artinya tidak ada hubungan linier variabel independen belanja langsung terhadap variabel dependen pengentasan kemiskinan.

Nilai koefisien beta (dalam kolom standardized coefficient beta) sebesar -0,078 atau jika dibuat dalam persen menjadi $-7,8 \%$ menunjukan bahwa pengaruh sebesar ini tidak signifikan karena nilai signifikansi / probabilitas hasil perhitungan yang tertera dalam kolom sig sebesar 0,305 > 0,05 .

\section{Pengaruh antara Variabel Independen Belanja Tidak Langsung terhadap Variabel Dependen Pengentasan Kemiskinan.}

Dengan hipotesis :

1. H0 : Tidak ada pengaruh linier variabel independen belanja tidak langsung terhadap variabel dependen pengentasan kemiskinan

2. H1 : Adanya pengaruh linier variabel independen belanja tidak langsung terhadap variabel dependen pengentasan kemiskinan

Dari hasil perhitungan dengan menggunakan SPSS yang tertera pada kolom t pada tabel Coefficients diatas untuk menunjukan adanya hubungan linier variabel independen belanja tidak langsung dengan variabel dependen pengentasan kemiskinan ialah sebesar 2.877.

Menentukan besarnya angka t tabel / nilai kritis dari tabel t dengan ketentuan sebagai berikut :

Menentukan besarnya taraf signifikansi sebesar 0,05 dan degree of freedom DF dengan ketentuan : $\mathrm{DF}=\mathrm{n}-(\mathrm{K}+1)$ atau $\mathrm{DF}=90-(3+1)$ dari ketentuan tersebut diperoleh angka t tabel untuk uji dua sisi adalah sebesar 1,662

Dalam pengujian hipotesis t kriterianya sebagai berikut :

Jika thitung $\geq \mathrm{t}$ tabel, maka $\mathrm{H} 0$ di tolak dan $\mathrm{H} 1$ diterima

Jika t hitung $\leq \mathrm{t}$ tabel, maka $\mathrm{H} 0$ diterima dan $\mathrm{H} 1$ ditolak

Untuk menunjukan pengaruh signifikan atau tidak kriterianya sebagai berikut :

Jika Sig $\leq 0,05$, maka berpengaruh signifikan

Hasil Pengujian :

Jika Sig $\geq 0,05$, maka tidak berpengaruh signifikan

Hasil dari perhitungan dengan menggunakan SPSS menunjukan angka t hitung sebesar $2.877>$ 1,662, dengan demikian keputusanya adalah H0 ditolak, dan H1 diterima. Artinya ada hubungan linier variabel independen belanja tidak langsung terhadap variabel dependen pengentasan kemiskinan.

Nilai koefisien beta ( dalam kolom standardized coefficient beta) sebesar 0.346 atau jika dibuat dalam persen menjadi 34,6\% menunjukan bahwa pengaruh sebesar ini tidak signifikan karena nilai signifikansi / probabilitas hasil perhitungan yang tertera dalam kolom sig sebesar 0,05 .

\section{Pengaruh antara Variabel Independen Pertumbuhan Ekonomi terhadap Variabel Dependen Pengentasan Kemiskinan.}

Dengan hipotesis :

1. H0 : Tidak ada pengaruh linier variabel independen pertumbuhan ekonomi terhadap variabel dependen pengentasan kemiskinan

2. $\quad \mathrm{H} 1$ : Adanya pengaruh linier variabel independen pertumbuhan ekonomi terhadap variabel dependen pengentasan kemiskinan 
Dari hasil perhitungan dengan menggunakan SPSS yang tertera pada kolom t pada tabel coefficients diatas untuk menunjukan adanya hubungan linier variabel independen pertumbuhan ekonomi dengan variabel dependen pengentasan kemiskinan ialah sebesar 4.309

Menentukan besarnya angka t tabel / nilai kritis dari tabel t dengan ketentuan sebagai berikut :

Menentukan besarnya taraf signifikansi sebesar 0,05 dan degree of freedom DF dengan ketentuan : $\mathrm{DF}=\mathrm{n}-(\mathrm{K}+1)$ atau $\mathrm{DF}=90-(3+1)$ dari ketentuan tersebut diperoleh angka $\mathrm{t}$ tabel untuk uji dua sisi adalah sebesar 1,662

Dalam pengujian hipotesis t kriterianya sebagai berikut :

Jika thitung $\geq \mathrm{t}$ tabel, maka $\mathrm{H} 0$ di tolak dan $\mathrm{H} 1$ diterima

Jika t hitung $\leq \mathrm{t}$ tabel, maka $\mathrm{H} 0$ diterima dan $\mathrm{H} 1$ ditolak

Untuk menunjukan pengaruh signifikan atau tidak kriterianya sebagai berikut :

Jika sig $\leq 0,05$, maka berpengaruh signifikan

Jika sig $\geq 0,05$, maka tidak berpengaruh signifikan

Hasil Pengujian :

Hasil dari perhitungan dengan menggunakan SPSS menunjukan angka t hitung sebesar 4.309> 1,662, dengan demikian keputusanya adalah $\mathrm{H} 0$ ditolak, dan $\mathrm{H} 1$ diterima. Artinya ada hubungan linier variabel independen pertumbuhan ekonomi terhadap variabel dependen pengentasan kemiskinan.

Nilai koefisien beta ( dalam kolom standardized coefficient beta) sebesar -0,491 atau jika dibuat dalam persen menjadi 49,1\% menunjukan bahwa pengaruh sebesar ini signifikan karena nilai signifikansi / probabilitas hasil perhitungan yang tertera dalam kolom sig sebesar $0,00<0,05$.

\section{Melihat Kelayakan Model Regresi Struktur II}

Untuk mengetahui model Regresi yang dibuat telah benar adalah dengan menggunakan pengujian dua cara yaitu pertama menggunakan nilai $\mathrm{F}$ pada tabel keluaran ANOVA, dan kedua dengan cara menggunakan nilai Probabilitas nilai Sig pada tabel keluaran ANOVA.

Tabel. 9. Anova

\begin{tabular}{|c|c|c|c|c|c|c|}
\hline Model & & Sum of Squares & $\mathrm{df}$ & Mean Square & $\mathrm{F}$ & Sig. \\
\hline \multirow{3}{*}{1} & Regression & 2.868 & 3 & .956 & 42.289 & $.000^{\circ}$ \\
\hline & Residual & 1.944 & 86 & .023 & & \\
\hline & Total & 4.811 & 89 & & & \\
\hline
\end{tabular}

\section{Uji Hipotesis Menggunakan Angka F}

Hipotesis :

1. HO : Tidak ada pengaruh linier variabel independen belanja langsung, belanja tidak langsung dan pertumbuhan ekonomi terhadap variabel dependen pengentasan kemiskinan

2. H1 : ada hubungan linier variabel independen belanja langsung, belanja tidak langsung dan pertumbuhan ekonomi terhadap variabel dependen pengentasan kemiskinan

Nilai F hitung dari keluaran SPSS ialah 42.289 
Menghitung nilai $\mathrm{F}$ tabel dengan ketentuan nilai besar nilai taraf signifikasi sebesar 0,05 dan nilai DF / Vektor 1 : jumlah variabel -1 atau 4-1 = 3 dan dumerator vektor : jumlah kasus jumlah variabel atau $90-4=86$ dengan ketentuan tersebut diperoleh angka $F$ tabel sebesar 2,480

Dengan kriteria pengambilan keputusan hasil pengujian hipotesis

Jika $\mathrm{F}$ hitung $\geq \mathrm{F}$ tabel, maka $\mathrm{H} 0$ ditolak $\mathrm{H} 1$ dan diterima.

Jika $\mathrm{F}$ hitung $\leq \mathrm{F}$ tabel, maka $\mathrm{H} 0$ diterima dan $\mathrm{H} 1$ ditolak

Hasil perhitungan dengan SPSS didapat angka $\mathrm{F}$ hitung sebesar $42.289>\mathrm{F}$ tabel sebesar 2,480. Dengan demikian H0 ditolak, dan H1 diterima dengan demikian ada pengaruh linier variabel independen belanja langsung, belanja tidak langsung dan pertumbuhan ekonomi terhadap variabel dependen pengentasan kemiskinan adalah model regresi diatas sudah layak dan benar dengan nilai Sig 0,000.

\section{Pembahasan}

Berdasarkan hasil penghitungan yang dilakukan, maka didapatkan hasil bahwa alokasi belanja yang dianggarkan pemerintah dalam tujuannnya untuk meningkatkan pertumbuhan ekonomi dan pada akhirnya mengentaskan kemiskinan yang ada di kabupaten dan kota Sulawesi Utara ternyata pengaruh yang diberikan oleh kedua alokasi utama belanja pemerintah daerah ini baik belanja langsung maupun belanja tidak langsung secara bersama-sama belum memberikan pengaruh yang cukup signifikan. Bahkan dari dua alokasi belanja utam pemerintah daerah ini ternyata alokasi belanja tidak langsung yang justru memberikan pengaruh yang positif dan signifikan terhadap pertumbuhan ekonomi di kota dan kabupaten se Sulawesi Utara. Hal ini tentu menjadi pekerjaan rumah bagi pemerintah kabupaten/kota dikarenakan alokasi belanja langsung yang sebenarnya pengalokasiaannya untuk pembangunan justru kurang memberi pengaruh yang signifikan terhadap perkembangan perekonomian, padahal melalui alokasi belanja langsung inilah pemerintah punya peran besar untuk meningkatkan perekonomian melalui pengalokasian anggaran pembangunan atau infrastruktur agar laju perekonomian dapat meningkat. Hal ini apabila ditarik kebelakang maka dapat dipahami bahwa sebagian besar daerah kabupaten dan kota di Sulawesi Utara masih bergantung pada anggaran perimbangan dari pemerintah pusat sehingga pengalokasian jumlah anggaran juga masih harus menerima banyak bimbingan dari pemerintah pusat dikarenakan masih digolongkan sebagai daerah dengan tingkat kemandirian rendah. Kemandirian daerah yang berperan besar atas pengalokasian anggaran nantinya di daerah tentunya perlu untuk ditingkatkan dengan membangun perekonomian daerah yang semakin berkembang serta konsisten membuka sumber-sumber perekonomian baru untuk dapat terus meningkatkan kemandirian. Dengan tingkat kemandirian yang semakin tinggi maka akan semakin membuat pemerintah di daerah punya kewenangan lebih besar dalam mengatur pengalokasian anggaran yang dimiliki ke sektor-sektor potensial yang dimiliki. Hal ini memungkinkan dikarenakan anggaran yang digunakan merupakan anggaran pendapatan dari daerah itu sendiri.

\section{KESIMPULAN DAN SARAN}

\section{Kesimpulan}

Berdasarkan hasil analisis serta pembahasan maka dapat disimpulkan sebagai berikut:

1) Belanja langsung tidak berpengaruh terhadap pertumbuhan ekonomi.

2) Belanja tidak langsung berpengaruh signifikan terhadap pertumbuhan ekonomi.

3) Pertumbuhan ekonomi berpengaruh signifikan terhadap pengentasan kemiskinan. 
4) Belanja langsung tidak berpengaruh terhadap pengentasan kemiskinan baik secara langsung maupun tidak langsung.

Belanja tidak langsung berpengaruh terhadap pengentasan kemiskinan baik secara langsung maupun tidak langsung.

\section{Saran}

a. Perlu adanya upaya untuk meningkatkan kemandirian yang dimiliki oleh kota/kabupaten di Sulawesi Utara dalam hal pengelolaan fiscal sehingga pembangunan yang dilakukan juga bisa berjalan dengan lebih baik lagi dikarenakan kemampuan keuangan daerah sudah semakin meningkat

b. Perlu adanya tambahan alokasi belanja langsung di dalam penganggaran agar dapat memaksimalkan upaya pengentasan kemiskinan dengan cara mengambil atau merelokasi anggaran-anggaran lain yang kurang mengena.

\section{DAFTAR PUSTAKA}

Asfia Murni, 2016, Ekonomika Makro (Edisi Revisi). Penerbit Refika Aditama.

Broadley Jordan. 2014. What is Poverty Alleviation. Borgenproject.org.

Maipita Indra, 2014. Mengukur Kemiskinan dan Distribusi Pendapatan. Edisi I. UPP STIM YKPN.

Rarity, 2013, Upaya Pemerintah Untuk Mengatasi Kemiskinan di Indonesia. Blogspot.co.id.

Sadono Sukirno, 2006, Ekonomi Pembangunan Proses masalah dan Dasar Kebijakan, cetakan ketiga, Penerbit Kencana, Jakarta.Aisyah, 